\title{
Detection of diketopiperazine and pyrrolnitrin, compounds with anti-Pythium insidiosum activity, in a Pseudomonas stutzeri environmental strain
}

\author{
Yordhathai Thongsri ${ }^{\text {, }}$ Chantana Aromdee ${ }^{\mathrm{b}}$, Chavi Yenjaic, Som dej Kanokmedhakul', Angkana Chaiprasert ${ }^{\mathrm{d}}$, Petr Hamale, \\ Chularut Prariyachatigulf
}

\begin{abstract}
Aims. Screening of bacterial flora for strains producing metabolites with inhibitory effects on the human pathogenic oomycete Pythium insidiosum. Separation and characterization of extracts from Pseudomonas stutzeri with anti-Pythium inhibitory activity. Search for genes with anti-Pythium effect within the genome of $P$. stutzeri.

Methods. A total of 88 bacterial strains were isolated from water resources in northeastern Thailand. Two screening methods were used to establish their inhibitory effects on P. insidiosum. One strain, P. stutzeri ST1302 was randomly chosen, and the extract with anti-P. insidiosum activity was fractionated and subfractionated using liquid column chromatography and purified by thin layer chromatography. The chemical structure of purified fractions was determined by Fourier transform infrared spectroscopy, nuclear magnetic resonance and mass spectrometry. Further, search for genes involved in the anti-Pythium activity (phenazine-1-carboxylic acid, 2,4-diacetylphloroglucinol, pyoluteorin and pyrrolnitrin) was undertaken in this $P$. stutzeri strain using primers described in the literature.

Results. Anti-P. insidiosum activity was detected in 16 isolates (18.2\%). In P. stutzeri ST1302, a subfraction labeled PYK7 exhibited strong activity against this oomycete. It was assigned to the diketopiperazines as cyclo(D-Pro-L-Val). In the search for genes, one gene region was successfully amplified. This corresponded to pyrrolnitrin.

The results suggest the possibility of using the related metabolites against $P$. insidiosum. This is the first report on the inhibitory effects of $P$. stutzeri against this oomycete. The results may contribute to the development of antimicrobial drugs/probiotics against pythiosis.
\end{abstract}

Key words: Pythium insidiosum, Pseudomonas stutzeri, antimicrobial, diketopiperazine, gene, pyrrolnitrin

Received: June 27, 2012; Accepted: September 6, 2012; Available online: November 13, 2012

http://dx.doi.org/10.5507/bp.2012.090

${ }^{a}$ Faculty of Graduated School, Khon Kaen University, Khon Kaen, Thailand

${ }^{b}$ Department of Pharmaceutical Chemistry, Faculty of Pharmaceutical Sciences, Khon

Kaen University, Khon Kaen, Thailand

'Department of Organic Chemistry, Faculty of Sciences, Khon Kaen University, Khon Kaen, Thailand

${ }^{d}$ Department of Microbiology, Faculty of Medicine, Siriraj Hospital, Mahidol University, Bangkok, Thailand

${ }^{e}$ Department of Microbiology, Faculty of Medicine and Dentistry, Palacky University Olomouc and University Hospital Olomouc, Czech Republic

${ }^{f}$ Centre for Research and Development of Medical Diagnosis Laboratories, Faculty of Associated Medical Sciences, Khon Kaen University, Khon Kaen, Thailand

Corresponding author: Petr Hamal, e-mail: petr.hamal@fnol.cz

\section{INTRODUCTION}

Pythiosis is a life-threatening disease caused by the oomycete Pythium insidiosum, a fungus-like organism belonging to the kingdom Chromista and based on DNA sequences, closely related to diatoms and golden-brown algae ${ }^{1,2}$. The genus Pythium comprises over 150 described species but only $P$. insidiosum is capable of infecting mammalian hosts such as cats, dogs, horses, cattle and also humans ${ }^{3-7}$. The first report of human pythiosis was that of a patient in Thailand and, since then, other cases have been reported in tropical and subtropical regions worldwide $^{3,4}$. Clinical forms are usually classified as cutaneous/ subcutaneous, ophthalmic, systemic and disseminated and are associated with high morbidity and mortality rates because of lack of specific symptoms and limited diagnostic tools ${ }^{3,8}$.
In terms of epidemiology, pythiosis is considered an endemic disease restricted mostly to Thailand. This territory consists of many aquatic regions with environments suitable for the life cycle of $P$. insidiosum ${ }^{8,9}$. Its natural habitat is stagnant, swampy areas, muddy water and wet fields. The oomycete was isolated from $21.6 \%$ of aquatic cultivated resources in northern Thailand ${ }^{10}$. It has now been demonstrated that watered areas, e.g. rice paddies, irrigation channels and reservoirs, are all potential resources of this emerging pathogen ${ }^{10}$.

Currently, there are neither effective antimicrobials nor vaccines against pythiosis ${ }^{8,11-14}$. Unlike fungi, $P$. insidiosum as an oomycete lacks ergosterol in the cell membrane which is the target of most antifungal drugs ${ }^{8,15}$. Therefore, attempts to treat animals or humans with antimycotics either in monotherapy or in combination have yielded variable and contradictory results ${ }^{11,16}$. The effectiveness of 
a vaccine from crude protein is $\sim 50 \%$ for human, $\sim 30 \%$ for canine and $\sim 60 \%$ for equine pythiosis ${ }^{8,17}$. This has led to research on therapeutic alternatives, particularly compounds from medicinal plants and microorganisms. To date, a large number of microbes have been investigated, including the genera Pseudomonas, Bacillus and Streptomyces known to produce a heterogeneous group of potent antimicrobial metabolites ${ }^{18,19}$. Examples of these are 2,4-diacetylphloroglucinol, pyoluteorin, pyrrolnitrin, hydrogen cyanide, hydrolytic enzymes, iron-chelating siderophores, and several cyclic lipodepsipeptides ${ }^{20,21}$. Further, several Streptomyces strains have been found to produce phosphomycin, albopeptin $\mathrm{B}$, tautomycin, tautomycetin, and ezomycin S (ref. ${ }^{22}$ ).

The purpose of this study was to screen bacterial strains from aquatic environments in the northeastern area of Thailand for their ability to inhibit the growth of $P$. insidiosum. Further, metabolites of one Pseudomonas stutzeri strain chosen for its anti-Pythium activity were studied and the genome of this bacterial strain was screened for genes encoding compounds with anti-Pythium effect.

\section{MATERIALS AND METHODS}

\section{Microorganisms for testing}

Eighty-eight bacterial isolates, defined morphologically, were obtained from water resources in the region of Khon Kaen, a city located in the northeastern part of Thailand. All isolates were stored in Difco Skim Milk (BD Diagnostic Systems) $100 \mathrm{mg} / \mathrm{mL}$ with $33 \%$ of glycerol at $-20{ }^{\circ} \mathrm{C}$ until tested. One strain of $P$. insidiosum SIMI6666, isolated from a corneal ulcer and identified by Angkana Chaiprasert, Department of Microbiology, Mahidol University, Thailand, was used for demonstration of growth inhibition.

\section{Testing of bacteria for anti-Pythium activity}

Two different techniques were used for testing the inhibitory activity against $P$. insidiosum. Bacterial cultures were grown in $100 \mathrm{~mL}$ sterile bottles containing $25 \mathrm{~mL}$ of the Brain Heart Infusion (BHI) Broth (BD Diagnostic Systems) and incubated at $37^{\circ} \mathrm{C}$ in a shaking incubator (VWR 1575 Signature Benchtop, Shel Lab) at $200 \mathrm{rpm}$ for 3 days. Cells were removed by centrifugation at $8000 \times g$ for $15 \mathrm{~min}$. Supernatants were filtered aseptically through 0.45 - $\mu$ m-pore-sized membrane filters (Millipore). Filtrates were stored at $4{ }^{\circ} \mathrm{C}$.

For the first technique, $100 \mu \mathrm{L}$ of the filtrate were spread on the surface of a test plate with the Nutrient Agar (Oxoid). A block sized $1 \times 1 \mathrm{~cm}$ was cut off from the Sabouraud Dextrose Agar (SDA; Oxoid) with P. insidiosum culture grown at $25^{\circ} \mathrm{C}$ for 5 days and transferred to the center of the test plate. The plate was incubated at $25^{\circ} \mathrm{C}$ and checked after 3, 6 and 9 days for growth inhibition of the culture.

For the second technique, $5 \mathrm{~mL}$ of the filtrate were mixed with $15 \mathrm{~mL}$ of molten SDA. After solidification, the block from $P$. insidiosum culture was placed on the agar surface as described in the first technique.
Incubation and evaluation of growth inhibition were as described above.

In both techniques, SDA without the filtrate was added as a growth control.

\section{Identification of $\boldsymbol{P}$. stutzeri strain ST1302}

One strain identified biochemically using the Vitek 2 Test Card (bioMérieux) as P. stutzeri was randomly chosen from isolates showing inhibitory activity. It was named ST1302 and under this designation, it is available in the culture collection of the Centre for Research and Development, Medical Diagnosis Laboratories, Faculty of Associated Medical Sciences, Khon Kaen University, Khon Kaen, Thailand.

Identification of this strain was then verified by sequencing analysis. Genomic DNA was prepared using a standard method described by Marmur et al. ${ }^{23}$.

The $16 \mathrm{~S}$ rDNA region of the strain was amplified using PCR with universal primers, fD1 ( 5'-AGTTTGATCCTGGCTCA-3') and rP2 (5'-ACGGCTACCTTGTTACGACTT-3') (ref. ${ }^{24}$ ). PCR amplification was carried out in $100 \mu \mathrm{L}$ of reaction mixture which contained $5 \mathrm{ng}$ of genomic DNA, $1 \times$ reaction buffer (Promega), $200 \mu \mathrm{M}$ each dATP, dTTP, dGTP, and dCTP (Promega), $2 \mathrm{mM}$ of $\mathrm{MgCl}_{2}, 50 \mathrm{pmol}$ of each primer, and $2.5 \mathrm{U}$ of TaqDNA polymerase (Promega). Amplification was performed in the Robocycler Gradient 96 Temperature Cycler (Stratagene) with the cycling conditions as follows: initial denaturation at $95^{\circ} \mathrm{C}$ for $2 \mathrm{~min}$ followed by 30 cycles (denaturation: $95^{\circ} \mathrm{C}, 2 \mathrm{~min}$; annealing: $42{ }^{\circ} \mathrm{C}, 30 \mathrm{~s}$; extension: $72{ }^{\circ} \mathrm{C}, 4 \mathrm{~min}$ ) and final extension at $72{ }^{\circ} \mathrm{C}$ for $20 \mathrm{~min}$. The PCR product was detected by electrophoresis in $1 \%$ agarose gel (Serva Electrophoresis) with ethidium bromide $(0.5 \mu \mathrm{g} / \mathrm{mL})$ running in $1 \times$ TBE buffer $(90 \mathrm{mM}$ Tris-Borate, $2 \mathrm{mM}$ EDTA, pH 8.0) at $100 \mathrm{~V}$ for $1 \mathrm{~h}$. The amplicon was then submitted to the GeneProof a.s., Czech Republic for sequence determination. The sequence was compared and analyzed for the greatest similarity with the genomic databases which are published in the Entrez Nucleotide Database of the National Center for Biotechnology information (NCBI), using the BLAST algorithm (http://www. ncbi-nlm-nih.gov/).

\section{Extraction, purification and characterization of anti-Pythi- um metabolites from $\boldsymbol{P}$. stutzeri}

For preparation of crude extract of metabolites, a single colony of $P$. stutzeri ST1302 from the Nutrient Agar plate was inoculated into each of four $1000 \mathrm{~mL}$ bottles containing $500 \mathrm{~mL}$ of the BHI Broth and incubated on a rotary shaker at $200 \mathrm{rpm}$ at $37^{\circ} \mathrm{C}$ for 3 days. Then, 20 liters of cultured broth were centrifuged at $8000 \times g$ for $15 \mathrm{~min}$ and sterilized by filtration through a $0.45-\mu \mathrm{m}-$ pore-size membrane filter (Millipore). The cell-free filtrate was mixed three times with an equal volume of dichloromethane (Merck). The dichloromethane layer was then dried with anhydrous $\mathrm{Na}_{2} \mathrm{SO}_{4}$ (Merck) and concentrated by evaporation under reduced pressure in a rotary evaporator (Rotavapor R-210, Buchi Laboratory Equipment). 
For preparation of fractions from the crude extract, separation by liquid column chromatography (LCC) was used. The extract was applied on the top of a glass column filled with a slurry of silica gel $60(0.015-0.040$ $\mathrm{mm}$; Merck), which was preconditioned with dichloromethane. Gradient mixtures of dichloromethane and finally with methanol added were used as mobile phases. The eluent was collected. Fractions with similar patterns were combined and tested for anti-Pythium activity by the disc diffusion method as described below. The fractions with inhibitory activity were separated again using LCC with gradient mixtures of dichloromethane and hexane (Merck) as mobile phases. Thin layer chromatography was then used for differentiation of single fractions according to retention factors $\left(\mathrm{R}_{\mathrm{f}}\right)$ and for purity checking. Detection was done under exposure to UV light at 256 and $364 \mathrm{~nm}$.

The chemical structure of one purified fraction was determined by Fourier transform infrared spectroscopy (FTIR) followed by nuclear magnetic resonance (NMR) spectroscopy and mass spectrometry (MS). Infrared spectra were measured in potassium bromide discs at the wavelengths 450-4000 $\mathrm{cm}^{-1}$ and detected using the PE 1600 FTIR spectrometer (Perkin Elmer). NMR spectroscopy was carried out at the Faculty of Sciences, Chiang Mai University, Chiang Mai, Thailand. The following analyses were performed: proton and carbon NMR, double quantum filtered - correlation spectroscopy, heteronuclear multiple quantum coherence and heteronuclear multiple bond coherence. MS evaluating molecular weight of fractions was carried out at the Faculty of Sciences, Mahidol University, Bangkok, Thailand. The data were analyzed and chemical structures of the fractions were established.

\section{Disc diffusion method for determination of anti-Pythium} activity of $\boldsymbol{P}$. stutzeri metabolites

Using this method, both crude extract and purified fractions were tested for anti-Pythium activity. The test solution was prepared by dilution of $1 \mathrm{mg}$ of the dried filtrate in $1 \mathrm{~mL}$ of dichloromethane. Paper discs $(6.0 \mathrm{~mm}$ in diameter; Gibthai, Thailand) filled with $20 \mu \mathrm{L}$ of test solutions were placed on the SDA plate which was then inoculated by the SDA block with $P$. insidiosum as described above. A disc containing $20 \mu \mathrm{L}$ of dichloromethane only was included as a negative control. The plates were kept at room temperature for $2 \mathrm{~h}$ in a laminar flow box to allow diffusion of the test solution. They were then incubated at $25^{\circ} \mathrm{C}$ for 3,6 and 9 days. If inhibition of $P$. insidiosum growth around the disc was observed, the effect of the compound was evaluated as positive.

\section{Detection of anti-Pythium genes in $\boldsymbol{P}$. stutzeri}

Search for genes encoding compounds with antimicrobial inhibitory activity in $P$. stutzeri strain ST1302 was performed with five sets of primers: PCA2a (5'-TGCCAAGCCTCGCTCCAAC-3') and PCA3b (5'-CGCGTTGTTCCTCGTTCAT-3'); 30-84/1 (5'-CAGTTCATCCGGCGGGCTGCAG-3') and 30-84/2 ( 5'-CCCGTTTCAGTAAGTCTTCCATGATGCG-3') for phenazine-1-carboxylic acid; Ph12a ( 5'-GAGGACGTCGAAGACCACA-3') and Ph12b (5'-ACCGCAGCATCGTGTATGAG-3') for 2, 4-diacetylphloroglucinol; PltBf (5'-CGGAGCATGGACCCCCAGC-3') and PltBr ( 5'-GTGCCCGATATTGGTCTTGACCGAG-3') for pyoluteorin and Prncf (5'-CCACAAGCCCGGCCAGGAGC-3') and Prncr (5'-GAGAAGAGCGGGTCGATGAAGCC-3') for pyrrolnitrin $^{20,21,25,26}$. All primers were synthesized by Metabion International, Germany. DNA was prepared in the same way as for sequencing. PCR amplification was performed according to Kumar et al. ${ }^{27}$.

\section{RESULTS AND DISCUSSION}

Antimicrobial activity testing and molecular genetic identification of Pseudomonas stutzeri ST1302

All 88 bacterial isolates obtained from water resources were tested for activity against $P$. insidiosum. Using both

Table 1. Searching for genes with anti-Pythium insidiosum activity in the strain Pseudomonas stutzeri ST1302.

\begin{tabular}{lll}
\hline $\begin{array}{l}\text { Gene-specific } \\
\text { primer pair }\end{array}$ & $\begin{array}{l}\text { Antimicrobial product } \\
\text { (DNA size in bp) }\end{array}$ & $\begin{array}{l}\text { Presence }(+) \text { or absence }(-) \\
\text { of the product }\end{array}$ \\
\hline PCA2a-PCA3b & $\begin{array}{l}\text { Phenazine-1-carboxylic acid } \\
(1150)\end{array}$ & - \\
$30-84 / 1-30-84 / 2$ & $\begin{array}{l}\text { Phenazine-1-carboxylic acid } \\
(1200)\end{array}$ \\
Phl2a-Ph12b & $\begin{array}{l}\text { 2,4-diacetylphoroglucinol } \\
(745)\end{array}$ \\
PltBf-PltBr & $\begin{array}{l}\text { Pyoluteorin } \\
(773)\end{array}$ \\
PrnCf-PrnCr & Pyrrolnitrin \\
& $(719)$ \\
\hline
\end{tabular}


screening techniques, 16 isolates $(18.2 \%)$ were found to inhibit its growth. The correlation between techniques was $100 \%$.

Phenotypic identification of the strain $P$. stutzeri ST1302 was verified by sequencing. The 783-bp PCR product derived from the $16 \mathrm{~S}$ rDNA region revealed 98\% similarity to $P$. stutzeri strain SN1 (accession No. JF 461537.1) included in the NCBI database.

\section{Purification and characterization of metabolites with anti- Pythium activity}

Crude extract of the P. stutzeri strain ST1302 which was active against $P$. insidiosum using the disc diffusion method, was separated into 20 fractions with different $R_{f}$, but in only three was such activity detected. A fraction labeled F10, composed of eight subfractions, was chosen for testing inhibitory effects. Using the disc diffusion method, only a subfraction labeled PYK7 with $R_{f}=0.7$ exhibited anti-Pythium activity. This was selected, purified and analyzed in the light of its chemical structure. PYK7 was a white, crystalline powder. From the results of the FTIR analysis, the peak at $v>3000 \mathrm{~cm}^{-1}$ indicated a typical secondary amine. The peak at $v=1671 \mathrm{~cm}^{-1}$ corresponded to a carbonyl group. However, the peaks at $v$ $=1429-1295 \mathrm{~cm}^{-1}$ showed a difference in C-O- bonds. The MS data showed the molecular ion peak of the PYK7 substance at $\mathrm{m} / z 197(\mathrm{M}+1)$ with a molecular formula $\mathrm{C}_{10} \mathrm{H}_{17} \mathrm{~N}_{2} \mathrm{O}_{2}$ (Fig. 1). Based on the analysis of NMR spectra, this was assigned to diketopiperazines (DKPs) as cyclo(D-Pro-L-Val). DKPs are the smallest possible cyclic peptides commonly biosynthesized from amino acids by different organisms ${ }^{28}$. Due to their rigid structure, chiral nature and varied side chains, they are an attractive scaffold for drug design. Both natural and synthetic DKPs have a wide variety of biological activities including antitumor, antiviral, antifungal and antibacterial activities.

The data from all spectroscopic methods used were in agreement with those described in the literature. The chemical structure of PYK7 was determined by interpretation of the MS and NMR data and compared with appropriate data from the literature including physicochemical features $^{29}$. It was found that the main anti-Pythium compound is DKP. Jayatilake et al. reported the production of DKP from a Pseudomonas aeruginosa strain associated with an Antarctic sponge ${ }^{30}$. However, to the best of our knowledge, the production of DKP by $P$. stutzeri found

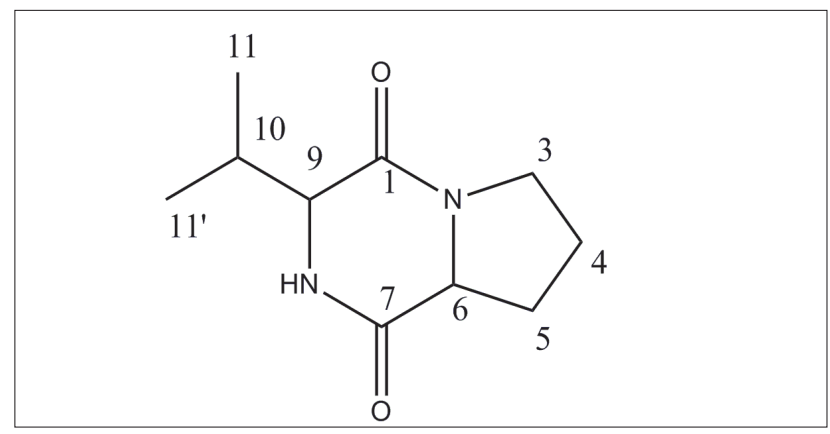

Fig. 1. Structure of cyclo(D-Pro-Val) $\left(\right.$ ref. $\left.^{35}\right)$. in our study is the first report of its occurrence in this species.

\section{Detection of antimicrobial genes}

The results of screening for genes with antimicrobial inhibitory activity in our P. stutzeri strain using PCR are summarized in Table 1. Only one gene region was successfully amplified. This corresponded to pyrrolnitrin. It is an antifungal antibiotic synthesized by some Pseudomonas spp. from tryptophan and initiated by a chloroperoxidase enzyme system ${ }^{31}$. Pyrrolnitrin inhibits fungal growth by inhibiting the respiratory electron transport system. It is most active against dermatophytic fungi, especially from the genus Trichophyton.

In accord with the amplification products described by Raaijmakers et al., no genes encoding phenazine-1-carboxylic acid, 2,4-diacetylphloroglucinol and pyoluteorin

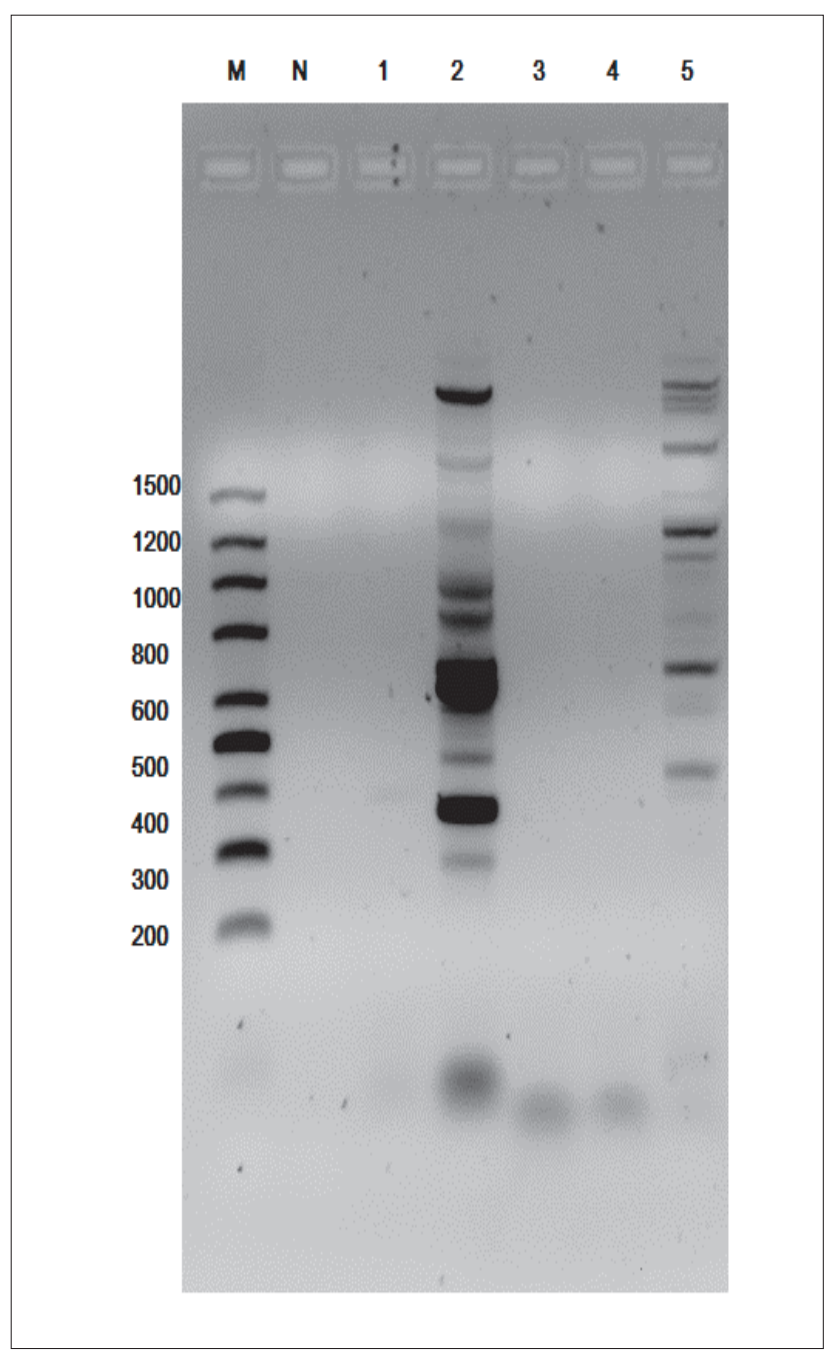

Fig. 2. Demonstration of searching results for genes with antiPythium insidiosum activity in the strain Pseudomonas stutzeri ST1302 by PCR. (M) 200-1500 bp ladder; (N) negative control; amplification by (1) phenazine-1-carboxylic acid primer pair, PCA2a-PCA3b; (2) phenazine-1-carboxylic acid primer pair, 30-84/1-30-84/2; (3) 2,4-diacetylphloroglucinol primer pair, Phl2a-Phl2b; (4) pyoluteorin primer pair, PltBf-PltBr and (5) pyrrolnitrin primer pair, PrnCf-PrnCr. Only amplification of the pyrrolnitrin gene was positive. 
were found in this study ${ }^{20,25,26}$. However, a product sized approximately $700 \mathrm{bp}$ corresponding to the pyrrolnitrin gene was amplified in our $P$. stutzeri strain and compared to strains of $P$. aeruginosa and $P$. fluorescens as reported earlier (Fig. 2) $\left(\right.$ ref. $^{20}$ ). Several strains belonging to the genus Pseudomonas derived from clinical materials and agricultural soil have been reported to promote the growth of plants and act as effective biocontrol agents ${ }^{18,32,33}$. Some metabolites of Pseudomonas spp. such as hydrogen cyanide and pyoluteorin were found to be active against plant pathogens like Pythium ultimum, Rhizoctonia solani, Phytophthora capsici and Fusarium oxysporum ${ }^{32}$. However, pyrrolnitrin was the only compound with known antimicrobial inhibitory activity (including anti-Pythium effects) we found in our P. stutzeri strain.

At present, there is no effective drug for treating pythiosis. Data on the antimicrobial activity of some aquatic bacteria suggest their metabolites could be used against $P$. insidiosum. This study is the first report on the inhibitory activity of $P$. stutzeri against this pathogenic oomycete and on its metabolite PYK7, identified as DKP cyclo(DPro-Val). However, understanding the contribution of this compound to the pathophysiology of $P$. insidiosum needs to be further explored. Our results may contribute to the development of novel antimicrobial drugs/probiotics.

\section{ACKNOWLEDGEMENTS}

This work was supported by the Thailand Research Fund (TRF) through the Royal Golden Jubilee Ph.D. Program (Grant no. PHD/0071/2551), and DBG 5080010 TRF Grant. The authors are grateful to the Centre for Research and Development of the Medical Diagnostic Laboratories, Faculty of Associated Medical Sciences, Khon Kaen University, Khon Kaen, Thailand, for using its laboratory facility.

Authorship contributions: YT, CP: literature search; YT, CP, PH: manuscript writing; CP: study design; YT, CA, CY, SK, AC: performance of experiments; YT, CP, PH: data analysis; YT, PH: data interpretation; YT: figures; $\mathrm{PH}, \mathrm{CP}$ : final approval.

Conflict of interest statement: The authors stated that there are no conflicts of interest regarding the publication of this article.

\section{REFERENCES}

1. Stalpers JA, Kirk PM, Minter DW, Cannon PF, editors. Dictionary of the Fungi. 10th ed. Wallingford: CABI Publishing; 2008.

2. Keeling PJ, Burger G, Durnford DG, Lang BF, Lee RW, Pearlman $\mathrm{RE}$, Roger AJ, Gray MW. The tree of eukaryotes. Trends Ecol Evol 2005;20(12):670-6.

3. Imwidthaya P. Human pythiosis in Thailand. Postgrad Med J 1994;70(826):558-60.

4. Bosco Sde M, Bagagli E, Araujo JP, Jr., Candeias JM, de Franco MF, Alencar Marques ME, Mendoza L, de Camargo RP, Alencar Marques S. Human pythiosis, Brazil Emerg Infect Dis 2005;11(5):715-8.

5. Bentinck-Smith J, Padhye AA, Maslin WR, Hamilton C, McDonald RK, Woody BJ. Canine pythiosis-isolation and identification of Pythium insidiosum. J Vet Diagn Invest 1989;1 (4):295-8.
6. Gaastra W, Lipman LJ, De Cock AW, Exel TK, Pegge RB, Scheurwater J, Vilela R, Mendoza L. Pythium insidiosum: an overview. Vet Microbiol 2010;146(1-2):1-16.

7. Pérez RC, Luis-León JJ, Vivas JL, Mendoza L. Epizootic cutaneous pythiosis in beef calves. Vet Microbiol 2005;109(1-2):121-8.

8. Krajaejun $T$, Sathapatayavongs $B$, Pracharktam R, Nitiyanant $P$, Leelachaikul P, Wanachiwanawin W, Chaiprasert A, Assanasen P, Saipetch M, Mootsikapun P, Chetchotisakd P, Lekhakula A, Mitarnun W, Kalnauwakul S, Supparatpinyo K, Chaiwarith R, Chiewchanvit S, Tananuvat N, Srisiri S, Suankratay C, Kulwichit W, Wongsaisuwan M, Somkaew S. Clinical and epidemiological analyses of human pythiosis in Thailand. Clin Infect Dis 2006;43(5):569-76.

9. Mendoza L, Hernandez F, Ajello L. Life cycle of the human and animal oomycete pathogen Pythium insidiosum. J Clin Microbiol 1993;31(11):2967-73.

10. Supabandhu J, Fisher MC, Mendoza L, Vanittanakom N. Isolation and identification of the human pathogen Pythium insidiosum from environmental samples collected in Thai agricultural areas. Med Mycol 2008;46(1):41-52.

11. Shenep JL, English BK, Kaufman L, Pearson TA, Thompson JW, Kaufman RA, Frisch G, Rinaldi MG. Successful medical therapy for deeply invasive facial infection due to Pythium insidiosum in a child. Clin Infect Dis 1998;27(6):1388-93.

12. Wanachiwanawin W, Thianprasit M, Fucharoen S, Chaiprasert A, Sudasna N, Ayudhya N, Sirithanaratkul N, Piankijagum A. Fatal arteritis due to Pythium insidiosum infection in patients with thalassaemia. Trans R Soc Trop Med Hyg 1993;87(3):296-8.

13. Loreto ES, Mario DA, Denardi LB, Alves SH, Santurio JM. In vitro susceptibility of Pythium insidiosum to macrolides and tetracycline antibiotics. Antimicrob Agents Chemother 2011;55(7):3588-90.

14. Bach BC, Leal DB, Ruchel JB, Souza Vdo C, Maboni G, Dal Pozzo M, Schlemmer KB, Alves SH, Santurio JM. Immunotherapy for pythiosis: Effect on NTPDase activity in lymphocytes of an experimental model. Biomed Pharmacother 2010;64(10):718-22.

15. Schlosser E, Gottlieb D. Sterols and the sensitivity of Pythium species to filipin. J Bacteriol 1966;91(3):1080-4.

16. Sudjaritruk T, Sirisanthana V. Successful treatment of a child with vascular pythiosis. BMC Infect Dis 2011;11:33.

17. Mendoza L, Newton JC. Immunology and immunotherapy of the infections caused by Pythium insidiosum. Med Mycol 2005;43(6):47786.

18. León M, Yaryura PM, Montecchia MS, Hernández Al, Correa OS, Pucheu NL, Kerber NL, García AF. Antifungal activity of selected indigenous Pseudomonas and Bacillus from the soybean rhizosphere. Int J Microbiol 2009;2009:1-9.

19. Oskay M. Antifungal and antibacterial compounds from Streptomyces strains. Afr J Biotechnol 2009;8(13):3007-17.

20. Raaijmakers JM, Vlami M, de Souza JT. Antibiotic production by bacterial biocontrol agents. Antonie Van Leeuwenhoek 2002;81(14):537-47.

21. Ramette A, Frapolli M, Défago G, Moënne-Loccoz Y. Phylogeny of $\mathrm{HCN}$ synthase-encoding hcnBC genes in biocontrol fluorescent pseudomonads and its relationship with host plant species and HCN synthesis ability. Mol Plant Microbe Interact 2003;16(6):525-35.

22. Shen Y-C. Recent progress on the research and development in agricultural antibiotics. Plant Prot Technol Ext 1997;17:35-7.

23. Marmur J. A procedure for the isolation of deoxyribonucleic acid from micro-organisms. J Mol Biol 1961;3(2):208-18.

24. Weisburg WG, Barns SM, Pelletier DA, Lane DJ. 16S ribosomal DNA amplification for phylogenetic study. J Bacteriol 1991;173(2):697703.

25. Raaijmakers JM, Weller DM, Thomashow LS. Frequency of antibioticproducing Pseudomonas spp. in natural environments. Appl Environ Microbiol 1997;63(3):881-7.

26. Mavrodi OV, McSpadden Gardener BB, Mavrodi DV, Bonsall RF, Weller DM, Thomashow LS. Genetic diversity of phID from 2,4-diacetylphloroglucinol-producing fluorescent Pseudomonas spp. Phytopathology 2001;91(1):35-43.

27. Kumar RS, Ayyadurai N, Pandiaraja P, Reddy AV, Venkateswarlu Y, Prakash O, Sakthivel N. Characterization of antifungal metabolite produced by a new strain Pseudomonas aeruginosa PUPa3 that exhibits broad-spectrum antifungal activity and biofertilizing traits. J Appl Microbiol 2005;98(1):145-54. 
28. Borthwick AD. 2,5-diketopiperazines: synthesis, reactions, medicinal chemistry, and bioactive natural products. Chem Rev. 2012;112(7):3641-716.

29. Adamczeski M, Reed AR, Crews P. New and known diketopiperazines from the Caribbean sponge, Calyx cf. podatypa. J Nat Prod 1995;58(2):201-8.

30. Jayatilake GS, Thornton MP, Leonard AC, Grimwade JE, Baker BJ. Metabolites from an Antarctic sponge-associated bacterium, Pseudomonas aeruginosa. J Nat Prod 1996;59(3):293-6.
31. Tripathi RK, Gottlieb D. Mechanism of action of the antifungal antibiotic pyrrolnitrin. J Bacteriol 1969;100(1):310-8.

32. Anjaiah V, Cornelis $P$, Koedam N. Effect of genotype and root colonization in biological control of fusarium wilts in pigeonpea and chickpea by Pseudomonas aeruginosa PNA1. Can J Microbiol 2003;49(2):85-91.

33. Kim KK, Kang JG, Moon SS, Kang KY. Isolation and identification of antifungal $\mathrm{N}$-butylbenzenesulphonamide produced by Pseudomonas sp. AB2. J Antibiot (Tokyo) 2000;53(2):131-6. 